\title{
RECENT RESEARCH DATA ON THE REMOVAL OF PHARMACEUTICALS FROM SEWAGE TREATMENT PLANTS (STP)
}

José Luiz Tambosi, Leonardo Yassuhiro Yamanaka, Humberto Jorge José e Regina de Fátima Peralta Muniz Moreira*

Departamento de Engenharia Química e Engenharia de Alimentos, Universidade Federal de Santa Catarina, Campus Universitário, 88040-900 Florianópolis - SC, Brasil

Horst Friedrich Schröder

Institute of Environmental Engineering, RWTH Aachen University, Krefelder Strasse 299, D-52056 Aachen, Germany

Recebido em 12/12/08; aceito em 24/7/09; publicado na web em 8/1/10

\begin{abstract}
Pharmaceutical compounds have been detected in sewage treatment plant (STP) effluents, surface waters and, less frequently, in groundwater and drinking water, all over the world. Different sources are responsible for their appearance in the aquatic environment, however, it is widely accepted that the main sources of this type of pollutant are STP effluents. The adverse effects of pharmaceuticals in the environment include aquatic toxicity, development of resistance in pathogenic bacteria, genotoxicity and endocrine disruption. Thus, the discharge of these compounds to the environment in STP effluents should be minimized.
\end{abstract}

Keywords: ecotoxicity; environment; pharmaceuticals.

\section{INTRODUCTION}

A great number of pharmaceutical compounds of different classes are consumed annually throughout the world. These drugs include antipyretics, analgesics, blood lipid regulators, antibiotics, antidepressants, chemotherapy agents, and contraceptive drugs. After administration, these compounds are partially metabolized and excreted in urine and feces, and subsequently enter sewage treatment plants (STPs) where they are treated together with other organic and inorganic constituents contained in wastewater. However, it has been shown that some of these pharmaceutical compounds, present in trace and ultra trace concentrations, are not completely removed during this treatment and as a result, they could be observed in STP effluents, ${ }^{1-4}$ surface waters ${ }^{5-8}$ and, less frequently, in groundwater ${ }^{9,10}$ and drinking water ${ }^{10-13}$ all over the world.

The frequent occurrence of pharmaceuticals in the aquatic environment as well as in drinking water supplies has raised concern regarding their potential impact on the environment and public health. The adverse effects caused by pharmaceutical compounds include aquatic toxicity, development of resistance in pathogenic bacteria, genotoxicity, and endocrine disruption. ${ }^{14-19}$ The presence of trace pharmaceutical and other xenobiotic compounds in drinking water supplies is another public health concern, since little is known about the potential chronic health effects associated with long-term ingestion of mixtures of these compounds..$^{20}$ Thus, an emerging issue in environmental science and engineering is to achieve effective removal of pharmaceutical compounds, along with other priority pollutants, from sources such as hospital and domestic wastewaters before their discharge into the environment.

As conventional water and wastewater treatment processes are unable for a reliable remove of some recalcitrant pharmaceuticals, it is necessary to introduce additional advanced treatment technologies prior to discharge into the environment. In the last few years, various advanced treatment technologies have been evaluated for this purpose, including membrane bioreactors (MBRs), ${ }^{4,21}$ advanced oxidation processes ${ }^{22,23}$ and adsorption onto activated carbon or other adsorbents. ${ }^{24-26}$

*e-mail: regina@enq.ufsc.br
The objective of this paper is to provide a broad overview, although not complete, of the actual knowledge regarding the environmental occurrence and fate of human and veterinary pharmaceuticals, as well as the removal efficiency rates of some pharmaceuticals in STPs. The environmental impacts associated with pharmaceuticals and the mechanisms which could be effective in reducing the inputs of pharmaceuticals to the aquatic environment will be discussed.

\section{Sources and applications of pharmaceuticals}

Pharmaceuticals, or medical drugs, are a group of chemical substances that have pharmacological properties. This group of substances includes both, inorganic and organic compounds, although most of the modern pharmaceuticals are small organic compounds with a molecular weight below 500 Daltons. ${ }^{27}$

These chemicals are moderately water soluble as well as lipophilic, bioavailable and biologically active. Pharmaceuticals are either administered topically (e.g., inhalation and skin application), internally (e.g., oral administration), or parenterally (e.g., injections and infusions) in households or in healthcare facilities such as hospitals and clinics. After administration, drug molecules are absorbed, distributed, partly metabolized, and finally excreted in original form, as conjugates or biodegraded in the feces or dissolved in urine. Metabolism either produces pharmacological active compounds or detoxifies excess drug molecules, as well as other toxic xenobiotics, via a series of enzymatic biotransformations and converts them to more polar and hydrophilic forms for a better renal excretion. ${ }^{28}$ Drug metabolism begins with various biochemical reactions including hydroxylation, epoxidation, reduction, and hydrolysis, in which functional groups are introduced or unmasked (phase I transformation). Subsequently, highly polar endogenous molecules, such as glucuronic acid, sulfate, and amino acids, attach to the drugs or metabolites of the phase I transformation to generate conjugates (phase II transformation), which are water-soluble and can be readily excreted in the urine. Certain drugs, non-therapeutic medical agents, and xenobiotics which cannot be metabolized because they are poor substrates for metabolizing enzymes such as cytochrome P-450. These compounds may be excreted slowly from the body without biotransformation. 
The consumption of pharmaceuticals is substantial. In the European Union (EU) about 3000 different substances are used in human medicine including analgesics and anti-inflammatory drugs, contraceptives, antibiotics, beta-blockers, lipid regulators, neuroactive compounds and many others. Also, a large number of pharmaceuticals are used in veterinary medicine, among them antibiotics and anti-inflammatory agents. ${ }^{29}$

Pharmaceutical compounds such as non-steroidal anti-inflammatory drugs (NSAIDs) and antibiotics are extensively used worldwide and their consumption predominantly in developed countries is assumed to be higher than several hundred tons per year. ${ }^{30}$

NSAIDs are a special group of pharmaceuticals that are often found as a persistent toxic waste and belong to the most widely applied drugs in the world. NSAIDs have three main benefits: lower inflammatory response; reduction of pain from inflammation (analgesic effects) and lowering of fever (antipyretic effects). In Spain, 55\% of the Top 200 drugs consumed are ingested orally, and approximately $5 \%$ of them are NSAIDs. ${ }^{31}$ Some important examples belonging to this family of drugs are acetylsalicylic acid, acetaminophen, ibuprofen, naproxen, diclofenac and ketoprofen, although there are more than 50 different types available commercially.

Antibiotics are a group of pharmaceuticals used for the treatment of both, bacterial and fungal infections of humans and animals. Many of the antibiotics are derived wholly or partially from certain microorganisms, but some are synthetic. ${ }^{28}$ Antibiotics are extensively used worldwide and their global annual consumption has been estimated to be between 100,000 and 200,000 tons. ${ }^{32}$ In the US, over 20,000 tons of antibiotics are produced annually, with approximately $60 \%$ for human use and $40 \%$ for veterinary applications. ${ }^{6}$ In Germany the total consumption of antibiotics in human medicine has been calculated as being approximately 400 tons p.a., two thirds of which after application are excreted into the sewage system as the main route of discharge. ${ }^{33}$ About 50,000 preparations of pharmaceuticals have been registered in Germany for human use, 2,700 of which accounted for $90 \%$ of the total consumption and these, in turn, contain about 900 different active substances. ${ }^{10}$ In China, statistics indicate that more than $70 \%$ of drug prescriptions are for antibiotics, as compared to $30 \%$ in western countries. ${ }^{34}$

Data on the exact production of pharmaceutical compounds usually are not published in the literature, and few data on the consumption of these compounds have been reported. Table 1 shows the annual consumption of selected drugs in different countries. Data concerning the consumption of pharmaceutical compounds in Brazil were not found.

\section{Environmental concentrations}

There are several possible sources and routes which lead to the

Table 1. Annual consumption (t/year) of different classes of prescribed drugs for different countries ${ }^{29,35,36}$

\begin{tabular}{|c|c|c|c|c|c|c|c|}
\hline Compound (Class) & $\begin{array}{c}\text { Australia } \\
1998\end{array}$ & $\begin{array}{c}\text { Austria } \\
1997\end{array}$ & $\begin{array}{c}\text { Denmark } \\
1997\end{array}$ & $\begin{array}{c}\text { England } \\
2000\end{array}$ & $\begin{array}{c}\text { Germany } \\
2001\end{array}$ & $\begin{array}{l}\text { Italy } \\
2001\end{array}$ & $\begin{array}{l}\text { Switzerland } \\
2004\end{array}$ \\
\hline Acetaminophen (Antiphogistic) & $295.9(1)$ & $35.08(2)$ & $295.9(1)$ & $390.9(1)$ & $621.65(2)$ & - & $95.20(1)$ \\
\hline Acetylsalicylic acid (Antiphogistic) & $20.4(9)$ & $78.45(1)$ & $0.21(7)$ & $18.11(22)$ & $836.26(1)$ & - & $43.80(3)$ \\
\hline Atenolol (Betablocker) & $5.2(28)$ & - & - & $28.98(13)$ & - & $22.07(4)$ & $3.20(9)$ \\
\hline Benzafibrate (Lipid regulating agent) & - & $4.47(17)$ & - & - & - & $7.60(8)$ & $0.757(15)$ \\
\hline Carbamazepine (Antiepileptic) & $9.97(18)$ & $6.33(14)$ & - & $40.35(8)$ & $87.60(12)$ & - & $4.40(8)$ \\
\hline Cimetidine (Antiacidic) & - & - & - & $35.65(11)$ & - & - & $0.063(20)$ \\
\hline Diazepam (Tranquillizer) & - & - & $0.21(8)$ & - & - & - & $0.051(21)$ \\
\hline Diclofenac (Tranquillizer) & $4.4(33)$ & $6.14(15)$ & - & $26.12(16)$ & $85.80(14)$ & - & $4.50(7)$ \\
\hline Erythromycin (Antibiotic) & $10.9(16)$ & - & - & $26.49(15)$ & - & - & - \\
\hline Furosemide (Diuretic) & $5.4(27)$ & - & $3.74(1)$ & - & - & $6.40(19)$ & $1.00(14)$ \\
\hline Gemfibrozil (Lipid regulating agent) & $20(10)$ & - & - & - & - & - & $0.399(18)$ \\
\hline Ibuprofen (Antiphogistic) & $14.2(13)$ & $6.7(13)$ & $0.03(19)$ & $162.2(3)$ & $344.89(5)$ & $1.9(15)$ & $25.00(4)$ \\
\hline Iopromide (X-ray contrast media) & - & - & - & - & $64.06(19)$ & - & $6.90(5)$ \\
\hline Ketoprofen (Antiphogistic) & $4.5(31)$ & - & - & - & - & - & - \\
\hline Metoprolol (Betablocker) & $6.2(26)$ & $2.44(20)$ & - & - & $92.97(11)$ & - & $3.20(10)$ \\
\hline Metformin (Antidiabetic) & $90.9(2)$ & $26.38(3)$ & - & $205.8(2)$ & $516.91(3)$ & - & $51.40(2)$ \\
\hline Naproxen (Antiphogistic) & $22.8(7)$ & $4.63(16)$ & - & $35.07(12)$ & - & - & $1.70(12)$ \\
\hline Ranitidine (Antiacidic) & $33.7(5)$ & - & - & $36.32(10)$ & $85.81(13)$ & $26.67(3)$ & $1.60(13)$ \\
\hline Roxithromycin (Antibiotic) & $3.8(36)$ & - & - & - & - & - & - \\
\hline $\begin{array}{l}\text { Salbutamol } \\
\text { (Bronchiodilator and Anti-asthma drug) }\end{array}$ & - & - & $0.17(9)$ & - & - & - & $0.035(22)$ \\
\hline $\begin{array}{l}\text { Salicylic acid } \\
\text { |(Metabolite of acetylsalicylic acid) }\end{array}$ & - & $9.57(11)$ & - & - & 71.67 (17) & - & $5.30(6)$ \\
\hline Sulfamethoxazole (Antibiotic) & $7.3(23)$ & - & - & - & - & - & - \\
\hline $\begin{array}{l}\text { Terbutalin } \\
\text { (Bronchiodilator and Anti-asthma drug) }\end{array}$ & - & - & $0.46(3)$ & - & - & - & $0.0099(23)$ \\
\hline Trimethoprim (Antibiotic) & $2.7(42)$ & - & - & - & - & - & - \\
\hline
\end{tabular}

Data in parentheses represent the position in the ranking list within a country. 
occurrence of pharmaceutical compounds in the aquatic environment. In the case of human pharmaceuticals, non-prescription drugs and some prescription drugs are consumed in households, and other prescription drugs are consumed in healthcare facilities such as hospitals and clinics. These drugs are partially metabolized and excreted in urine and feces reaching the sewer systems to be transported into the wastewater treatment plants. Some unused, surplus, or expired drugs may also be disposed into the toilets, although this practice nowadays sounds environmental unfriendly. Wastewaters from hospitals may be treated separately or combined with municipal wastewater in municipal STPs. ${ }^{37}$

According to Halling-Sørensen et al., ${ }^{14} 30$ to $90 \%$ of the doses of most antibiotics administered to humans and animals will be excreted with the urine as a pharmacological active substance. In veterinary medicine, antibiotic compounds can be used as growth promoters for livestock production, as therapeutics in livestock production, coccidiostatics for poultry production or as feed additives in fish farms. Due to the use in fish farms, some antibiotics, such as chloramphenicol and the oxytetracycline, have been detected in aquaculture pond sediment. ${ }^{38}$

In relation to environmental concerns, the occurrence of pharmaceuticals was first reported in the United States in treated wastewater, where clofibric acid in the range of $0.8-2 \mu \mathrm{g} / \mathrm{L}$ was found. ${ }^{39}$ In 1981 , pharmaceuticals were detected in rivers in the U.K. in concentrations of up to $1 \mu \mathrm{g} / \mathrm{L},{ }^{40}$ and ibuprofen and naproxen were identified in wastewater samples in Canada. ${ }^{41}$ In the last few years, knowledge regarding the environmental occurrence of pharmaceuticals has increased to a large extent due to the rapid development of analytical techniques able to determine polar pharmaceutical compounds even at trace and ultra trace concentrations. ${ }^{4,42-47}$

Different sources account for the appearance of these compounds in the aquatic environment. Currently it is accepted that the main sources for drugs in the environment are STP effluents. ${ }^{3,29}$ A vast number of pharmaceutical compounds have been detected in STP effluents, surface water and, less frequently, in groundwater and drinking water in Brazil, ${ }^{2,48}$ Canada,,${ }^{49,50}$ China, ${ }^{51,52}$ Germany, ${ }^{1,10}$ Italy, Spain, ${ }^{53,54}$ Switzerland ${ }^{29,55}$ and the United States. ${ }^{6,56}$

It is important to mention that in Brazil there is more expectation concerning the occurrence of pharmaceuticals in wastewater as a result of the lack of sewage treatment in the country. The main route for this type of contaminant in surface waters is the release of sewage without any treatment, as in many places there is a great lack of infrastructure in sanitation. In Brazil, only $20.2 \%$ of the cities collect and treat domestic sewage, $32 \%$ only have the service of collecting and in $47.8 \%$ of the cities, the sewage not-collected is released directly into surface waters. ${ }^{57}$

Table 2 presents a summary of the concentrations of the most frequently observed pharmaceuticals in STP effluents, surface water, groundwater and drinking water. In STP effluents in general a larger number of different pharmaceuticals and diagnostics occur at concentrations in the $\mathrm{ng} / \mathrm{L}$ to $\mu \mathrm{g} / \mathrm{L}$ range while their concentrations in rivers, lakes and seawaters were observed in the $\mathrm{ng} / \mathrm{L}$ range.

\section{Environmental impacts}

In the open literature and databases, ecotoxicological data are available for less than $1 \%$ of pharmaceuticals, and only a small number of new pharmaceuticals have undergone risk assessment using ecotoxicological tests. Pharmaceuticals are designed to target specific metabolic and molecular pathways in humans and animals, but they often have important side effects. When introduced into the environment, drugs may affect the same pathways in animals having identical or similar target organs, tissues, cells or biomolecules. It is important to recognize that for many drugs, their specific modes of actions are not well known and often not only one but many different modes of actions may occur. Toxicity experiments should be targeted and designed for specific targets of the pharmaceuticals, even in lower vertebrates and invertebrates, based on the hypothesis of similarity of modes of actions. Thus, ecotoxicity testing merely provides some indication of the acute effects (short-term exposure) in vivo in organisms of different trophic levels, and only scarce information about long-term (chronic) exposure. ${ }^{29}$

The effects of pharmaceuticals on human health should be examined qualitatively taking into account the particular concerns and needs of society according to the classes and products. In this regard, we can highlight the use of antibiotics as a major concern, according to the experts, due to the development of antibiotic resistances in bacterial populations. The increase in the use and in the different types of antibiotics over the past five decades has led to a selection of resistant bacteria, which resulted probably in irreversible longterm effects. ${ }^{66}$ Jørgensen and Halling-Sørensen ${ }^{67}$ have commented that the development of resistance is favored by exposure to low concentrations of such compounds.

Recently, some researchers investigated a specific group of chemical compounds present in the environment that is responsible for disruption of the endocrine system (hormonal) of human and animal organisms: these compounds are called endocrine disruptors (EDCs). Among this group of substances are also natural estrogens and contraceptives. Some authors report that, depending on the dose and time of exposure, it is possible that these substances may be related to diseases such as breast, testicular and prostate cancer, polycystic ovaries and the reduction in male fertility. ${ }^{18,19,68}$

Fishes belong to one of the most studied groups of organisms in terms of the effects of substances with estrogen activity in the development of anomalies in the reproductive system. According to Sumpter, ${ }^{15}$ investigations into how estrogenic substances affect the sexual functioning of fish began already in the 1980s.

The impact of chemicals such as pharmaceuticals may include all levels of the biological hierarchy: cells, organs, organisms, populations and ecosystems. Subtle effects may include genetic selection, endocrine disruption, genotoxicity and, subsequently, changes in the behavior and metabolic functioning of the species which comprise an ecosystem. ${ }^{67}$

Currently, two topics of the effects induced by pharmaceuticals in the environment became the most discussed: the development of bacterial resistances to antibiotics and assessments of disturbances in the endocrine system caused by substances such as estrogens. Other possible effects have been less widely discussed.

\section{Removal efficiency of pharmaceuticals in STPs}

The behavior and fate of pharmaceuticals and their metabolites in the aquatic environment is not well known. The low volatility of most pharmaceuticals indicates that their distribution in the environment will occur primarily by aqueous transport, but also via food chain dispersal.

In wastewater treatment, two elimination processes are generally important: adsorption to suspended solids (sewage sludge) and biodegradation. Adsorption is dependent on both, hydrophobic and electrostatic interactions of the pharmaceutical with particulates and microorganisms. Acidic pharmaceuticals, such as the NSAIDs acetylsalicylic acid, ibuprofen, fenoprofen, ketoprofen, naproxen, diclofenac and indomethacin, having $\mathrm{pKa}$ values ranging from 4.9 to 4.1 , as well as clofibric acid, bezafibrate (pKa 3.6) and gemfibrozil, occur as ions at neutral $\mathrm{pH}$, and have little tendency towards adsorption onto the sludge. But adsorption increases with lower $\mathrm{pH}$. At neutral $\mathrm{pH}$, these negatively charged pharmaceuticals therefore occur mainly dissolved in the wastewater phase. For these compounds, and the antitumor agent ifosfamide, sorption by non-specific interactions seems not to be relevant. ${ }^{69,70}$ 
Table 2. Concentrations of pharmaceuticals (ng/L) in STP effluents, surface water, groundwater and drinking water

\begin{tabular}{|c|c|c|c|c|c|}
\hline Compound (Class) & STP effluents & Surface water & Groundwater & Drinking water & Ref \\
\hline \multirow[t]{4}{*}{ Acetaminophen (Antiphogistic) } & - & - & 380 & - & 58 \\
\hline & - & 160 & - & - & 59 \\
\hline & $1.8-19$ & $4.1-73$ & - & - & 12 \\
\hline & - & 15 & - & 3 & 13 \\
\hline Acetylsalicylic acid (Antiphogistic) & - & 28.3-35.6 & - & - & 60 \\
\hline Amidotrizoic acid (X-ray contrast medium) & - & - & 1100 & - & 61 \\
\hline \multirow[t]{11}{*}{ Carbamazepine (Antiepileptic) } & $300-1200$ & - & - & - & 3 \\
\hline & $33-1318$ & - & - & - & 43 \\
\hline & 840 & - & - & - & 48 \\
\hline & - & 190 & - & - & 59 \\
\hline & $1000-1400$ & - & - & - & 4 \\
\hline & $73-729$ & $4.5-61$ & - & - & 12 \\
\hline & - & $65.4-75.1$ & - & - & 60 \\
\hline & - & - & 900 & - & 61 \\
\hline & - & - & - & 258 & 20 \\
\hline & - & 191 & - & 29 & 13 \\
\hline & 2100 & 250 & - & - & 1 \\
\hline Clofibric acid & $0.7-82$ & - & - & - & 43 \\
\hline \multirow{2}{*}{ (Metabolite of lipid regulating agents) } & - & - & - & $5.3-270$ & 62 \\
\hline & 360 & 66 & - & - & 1 \\
\hline \multirow[t]{2}{*}{ Diazepam (Tranquillizer) } & - & - & - & $19.6-23.5$ & 62 \\
\hline & - & $27.9-33.6$ & - & - & 60 \\
\hline \multirow[t]{7}{*}{ Diclofenac (Antiphogistic) } & $250-5450$ & - & - & - & 3 \\
\hline & $1200-1400$ & - & - & - & 4 \\
\hline & - & - & - & 6 & 62 \\
\hline & $8.8-127$ & $1.1-6.8$ & - & - & 12 \\
\hline & - & $9-282$ & - & - & 63 \\
\hline & - & - & 590 & - & 61 \\
\hline & 810 & 150 & - & - & 1 \\
\hline \multirow[t]{2}{*}{ Erythromycin (Antibiotic) } & $9-353$ & - & - & - & 43 \\
\hline & - & $<4-70$ & - & - & 8 \\
\hline Estriol (Hormone) & $8.9-25$ & - & - & - & 12 \\
\hline 17 -ethynylestradiol (Hormone) & 1.3 & - & - & - & 12 \\
\hline \multirow{3}{*}{ Estrone (Hormone) } & $30-48$ & - & - & - & 43 \\
\hline & $2.2-36$ & $1.7-5.0$ & - & - & 12 \\
\hline & $27-40$ & - & - & - & 49 \\
\hline \multirow[t]{2}{*}{17 -estradiol (Hormone) } & $<1.0$ & - & - & - & 12 \\
\hline & $15-21$ & - & - & - & 49 \\
\hline Gemfibrozil (Lipid regulating agent) & 400 & 52 & - & - & 1 \\
\hline \multirow[t]{9}{*}{ Ibuprofen (Antiphogistic) } & $20-1820$ & - & - & - & 3 \\
\hline & - & - & 3110 & - & 58 \\
\hline & $2600-5700$ & - & - & - & 64 \\
\hline & - & 270 & - & - & 59 \\
\hline & - & - & - & 3 & 62 \\
\hline & $10-137$ & $11-38$ & - & - & 12 \\
\hline & - & $61.3-115.2$ & - & - & 60 \\
\hline & - & $144-2370$ & - & - & 8 \\
\hline & 370 & 70 & - & - & 1 \\
\hline Iopamidol (X-ray contrast media) & - & - & 300 & - & 61 \\
\hline \multirow[t]{2}{*}{ Ketoprofen (Antiphogistic) } & 1.62 & - & - & - & 3 \\
\hline & 200 & - & - & - & 1 \\
\hline Lincomycin (Antibiotic) & - & - & 320 & - & 58 \\
\hline
\end{tabular}


Table 2. Cont.

\begin{tabular}{|c|c|c|c|c|c|}
\hline Compound (Class) & STP effluents & Surface water & Groundwater & Drinking water & Ref. \\
\hline \multirow[t]{5}{*}{ Naproxen (Antiphogistic) } & $290-5220$ & - & - & - & 3 \\
\hline & $1800-4600$ & - & - & - & 64 \\
\hline & $20-483$ & $1.8-18$ & - & - & 12 \\
\hline & - & $17-313$ & - & - & 63 \\
\hline & 300 & 70 & - & - & 1 \\
\hline \multirow[t]{2}{*}{ Norfloxacin (Antibiotic) } & $85-320$ & - & - & - & 51 \\
\hline & & - & - & - & \\
\hline \multirow[t]{2}{*}{ Ofloxacin (Antibiotic) } & $110-1000$ & - & - & - & 6 \\
\hline & $150-1081$ & - & - & - & 43 \\
\hline Phenazone (Antiphogistic) & - & - & 25 & - & 61 \\
\hline Propanolol (Betablocker) & - & $35-107$ & - & - & 8 \\
\hline Roxithromycin (Antibiotic) & $36-69$ & - & - & - & 65 \\
\hline Sotalol (Betablocker) & - & - & 560 & - & 61 \\
\hline \multirow[t]{10}{*}{ Sulfamethoxazole (Antibiotic) } & $10-90$ & - & - & - & 3 \\
\hline & - & - & 1110 & - & 58 \\
\hline & 310 & 300 & - & - & 6 \\
\hline & 600 & - & - & - & 64 \\
\hline & $46-317$ & - & - & & 43 \\
\hline & - & - & $50-80$ & - & 56 \\
\hline & $3.8-407$ & $1.7-36$ & - & - & 12 \\
\hline & - & - & 410 & - & 61 \\
\hline & - & 30 & - & - & 13 \\
\hline & - & $320-520$ & - & - & 7 \\
\hline Sulfamethazine (Antibiotic) & - & - & 360 & - & 58 \\
\hline \multirow[t]{3}{*}{ Tetracycline (Antibiotic) } & $180-620$ & - & - & - & 51 \\
\hline & - & - & 220 & - & 56 \\
\hline & - & $160-980$ & - & - & 7 \\
\hline \multirow[t]{6}{*}{ Trimethoprim (Antibiotic) } & $20-80$ & - & - & - & 3 \\
\hline & 180 & - & - & - & 6 \\
\hline & - & 20 & - & - & 59 \\
\hline & $120-230$ & - & - & - & 51 \\
\hline & $10-188$ & $3.2-5.3$ & - & - & 12 \\
\hline & - & $4-19$ & - & - & 8 \\
\hline
\end{tabular}

In general, sorption of acidic pharmaceuticals to sludge is suggested to be not very significant in the elimination of pharmaceuticals from wastewater and surface water. Therefore, levels of pharmaceuticals in digested sludge and sediments are suggested to be relatively low which has been demonstrated in several monitoring studies. ${ }^{71,72}$ However, basic pharmaceuticals and zwitterions can adsorb to sludge to a significant extent, as has been shown for fluoroquinolone antibiotics. ${ }^{73}$ For the hydrophobic synthetic steroid hormone $17 \alpha$-ethinylestradiol $\left(\log K_{\text {ow }}\right.$ 4.0) sorption to sludge is likely to play an important role in the removal from wastewater whereas degradation by sludge seems not to be significant. As a consequence, $17 \alpha$-ethinylestradiol occurs in digested sludge, where concentrations of $17 \mathrm{ng} / \mathrm{g}$ have been reported. ${ }^{74}$

When a pharmaceutical compound is present mainly in the dissolved phase, biodegradation is suggested to be the most important elimination process in wastewater treatment. This can occur either in aerobic (and anaerobic) zones in activated sludge treatment, or anaerobically in sewage sludge digestion. In general, biological decomposition of micro-pollutants, including pharmaceuticals, increases with an increased hydraulic retention time and with the age of the sludge applied in activated sludge treatment. For example, diclofenac has been shown to be significantly better biodegraded only when the sludge retention time was at least 8 days. ${ }^{75}$ In contrast, data reported by Metcalfe et $_{\text {al }}{ }^{76}$ indicate that the neutral drug carbamazepine, which is only very slightly biodegradable, is poorly eliminated (normally less than 10\%), regardless of the hydraulic retention times.

The parent pharmaceutical compounds are excreted as nonconjugated and conjugated polar metabolites. Conjugates later on can, however, be cleaved in STPs, resulting in the release of the active parent compound, as shown for estradiol, ${ }^{49,77}$ and the steroidal hormone contained in the contraceptive pill, $17 \alpha$-ethinylestradiol. ${ }^{78}$

Studies on the removal rates during STP treatment are mainly based on measurements of influent and effluent concentrations in STPs, and they vary according to the type of plant and treatment technology, hydraulic retention time, season and performance of the STP. Studies on the removal of pharmaceuticals in Brazilian STPs are rare and scattered. Stumpf $e t$ $a l .{ }^{2}$ and Ternes et $a l .{ }^{49}$ were the first to report the presence of hormones and anti-inflammatories in sewage, treated wastewater and water from rivers in the state of Rio de Janeiro. Table 3 shows the removal efficiency of pharmaceuticals in STPs and it can be seen that removal rates are variable, even for the same pharmaceutical compound in different STPs.

\section{Technical options to avoid pharmaceutical discharges into the aquatic environment}

Basically, four different approaches to improve removal of micropollutants from wastewater can be identified: optimization of 
Table 3. Influent and effluent concentrations and removal efficiencies of pharmaceuticals in STPs (different equipment, countries, and sampling seasons)

\begin{tabular}{|c|c|c|c|c|}
\hline Compound (Class) & Influent concentration (ng/L) & Effluent concentration (ng/L) & $\begin{array}{l}\text { Removal efficiency } \\
\qquad \%)\end{array}$ & Ref. \\
\hline \multirow{2}{*}{ Acetaminophen (Antiphogistic) } & n.r. & n.r. & 91.93 & 79 \\
\hline & $5529-69570$ & 0 & 100 & 8 \\
\hline Acetylsalicylic acid (Antiphogistic) & $470-19400$ & $13-100$ & $90-100$ & 80 \\
\hline \multirow[t]{4}{*}{ Benzafibrate (Lipid regulating agent) } & $1550-7600$ & $0-4800$ & $34-100$ & 65 \\
\hline & 420 & $0-850$ & $15-100$ & 81 \\
\hline & [1180] & {$[600-840]$} & $27-50$ & 2 \\
\hline & n.r. & n.r. & 83 & 1 \\
\hline \multirow[t]{5}{*}{ Carbamazepine (Antiepileptic) } & {$[750-1750]$} & {$[950-1500]$} & $0-20$ & 82 \\
\hline & $325-1850$ & $465-1594$ & $0-14$ & 65 \\
\hline & $20-300$ & $10-200$ & $<45$ & 80 \\
\hline & $40-2150$ & $20-1290$ & $0-25$ & 54 \\
\hline & n.r. & n.r. & 7 & 1 \\
\hline Clofibric acid & $338-651$ & 0 & 91 & 8 \\
\hline \multirow[t]{3}{*}{ (Metabolite of lipid regulating agents) } & {$[1000]$} & [680-880] & $15-34$ & 2 \\
\hline & $150-250$ & $150-250$ & 0 & 55 \\
\hline & n.r. & n.r. & 51 & 1 \\
\hline Diazepam (Tranquillizer) & $590-1180$ & $100-660$ & 93 & 83 \\
\hline \multirow[t]{6}{*}{ Diclofenac (Antiphogistic) } & $905-4114$ & $780-1680$ & $7-63$ & 65 \\
\hline & 3000 & 2500 & 17 & 37 \\
\hline & 350 & $170-350$ & $9-60$ & 81 \\
\hline & $901-1036$ & $261-598$ & 71 & 8 \\
\hline & $400-1900$ & $400-1900$ & 0 & 55 \\
\hline & n.r. & n.r. & 69 & 1 \\
\hline \multirow[t]{2}{*}{ Erythromycin (Antibiotic) } & $70-1200$ & $0-300$ & $43.8-100$ & 56 \\
\hline & $71-141$ & $145-290$ & 79 & 8 \\
\hline \multirow[t]{2}{*}{ Fenofibric acid (Metabolite of fenofibrate) } & [440] & [220-400] & $6-45$ & 2 \\
\hline & n.r. & n.r. & 64 & 1 \\
\hline \multirow[t]{2}{*}{ Gemfibrozil (Lipid regulating agent) } & {$[300]$} & [180-280] & $16-46$ & 2 \\
\hline & n.r. & n.r. & 69 & 1 \\
\hline \multirow[t]{6}{*}{ Ibuprofen (Antiphogistic) } & $2600-5700$ & $900-2100$ & $60-70$ & 64 \\
\hline & $1200-2679$ & $0-2400$ & $0-100$ & 65 \\
\hline & 13100 & $0-3800$ & $78-100$ & 81 \\
\hline & $300-1000$ & $1-200$ & $90-100$ & 80 \\
\hline & $12130-373110$ & $800-48224$ & $88-93$ & 54 \\
\hline & 2000-3000 & $600-800$ & $53-79$ & 55 \\
\hline \multirow[t]{5}{*}{ Ketoprofen (Antiphogistic) } & 2000 & $0-1250$ & $51-100$ & 81 \\
\hline & $100-300$ & $60-200$ & $0-80$ & 80 \\
\hline & $20-2510$ & $10-1500$ & $38-67$ & 54 \\
\hline & {$[550]$} & [180-300] & $48-69$ & 2 \\
\hline & $250-430$ & $150-240$ & $8-53$ & 55 \\
\hline Metoprolol (Betablocker) & n.r. & n.r. & 83 & 1 \\
\hline \multirow[t]{6}{*}{ Naproxen (Antiphogistic) } & $1800-4600$ & $800-2600$ & $40-55$ & 64 \\
\hline & 4900 & $150-1900$ & $55-98$ & 81 \\
\hline & $30-300$ & $10-200$ & $0-80$ & 80 \\
\hline & $1100-27400$ & $220-4280$ & $40-90$ & 54 \\
\hline & {$[600]$} & [100-540] & $15-78$ & 2 \\
\hline & n.r. & n.r. & 66 & 1 \\
\hline Norfloxacin (Antibiotic) & $110-460$ & $85-320$ & $5-78$ & 51 \\
\hline Ofloxacin (Antibiotic) & $470-1000$ & $110-1000$ & 77 & 6 \\
\hline
\end{tabular}


Table 3. Cont.

\begin{tabular}{|c|c|c|c|c|}
\hline Compound (Class) & Influent concentration (ng/L) & Effluent concentration (ng/L) & $\begin{array}{c}\text { Removal efficiency } \\
(\%)\end{array}$ & Ref. \\
\hline Propranolol (Betablocker) & n.r. & n.r. & 96 & 1 \\
\hline \multirow[t]{2}{*}{ Roxithromycin (Antibiotic) } & $25-117$ & $36-69$ & $27-44$ & 65 \\
\hline & n.r. & n.r. & 23 & 84 \\
\hline Sulfamethoxazole & $390-1000$ & 310 & 20 & 6 \\
\hline \multirow[t]{4}{*}{ (Antibiotic) } & 600 & 200 & 67 & 64 \\
\hline & 24-145 & $0-91$ & $32-66$ & 65 \\
\hline & n.r. & n.r. & 60 & 84 \\
\hline & $130-1250$ & $0-370$ & $17.8-100$ & 56 \\
\hline Tetracycline & $96-1300$ & $180-620$ & $7-73$ & 51 \\
\hline (Antibiotic) & $270-1200$ & $0-370$ & $67.9-100$ & 56 \\
\hline Trimethoprim & $590-1400$ & 180 & 69 & 6 \\
\hline \multirow[t]{4}{*}{ (Antibiotic) } & n.r. & n.r. & 74 & 84 \\
\hline & $120-320$ & $120-230$ & 62 & 51 \\
\hline & $50-1300$ & $0-550$ & $50-100$ & 56 \\
\hline & $213-300$ & $218-322$ & 3 & 8 \\
\hline
\end{tabular}

existing treatment technologies, upgrading existing treatment plants with new end-of-pipe technology, source separation methods, and source control measures. Improving wastewater treatment plants and applying source control measures are the traditional approaches for the improvement of quality of wastewater discharges into receiving waters. Source separation is a recent approach with an increasing acceptance in the wastewater treatment community. ${ }^{85}$

In terms of the aquatic environment, wastewater treatment is considered as the key step, at least to reduce inputs of human pharmaceuticals. As current systems are unable to remove some pharmaceuticals effectively, improvements and modifications of applied techniques are necessary. For example, increasing the sludge retention time (SRT) in biological treatment processes will facilitate the development of populations of slower growing bacteria and may enable them to adapt to the recalcitrant compounds and to improve biodegradability.

The alternative option for the degradation of recalcitrant organic pollutants such as pharmaceuticals in water and wastewater is the application of advanced treatment technologies. ${ }^{28,57}$ For the advance treatment biological techniques such as membrane bioreactors (MBRs), or physicochemical methods like advanced oxidation processes (AOPs), activated carbon adsorption (GAC) or membrane treatment applying nano filtration (NF) or reverse osmosis (RO) may develop as method of choice. These treatment processes can either eliminate such pollutants completely through mineralization or convert them to products which are less harmful to human health and the aquatic environment.

Membrane bioreactor (MBR) technology, the combination of a biological activated sludge process and a solid-liquid separation by membrane filtration, is considered the most promising development in microbiological wastewater treatment and its multiplied application led to a decrease of filtration membrane costs. Since high costs no longer limit the application of MBRs in industrial and municipal STPs, and new requirements are being set for wastewater treatment, MBRs may become the main treatment in direct or indirect recycling of wastewaters. ${ }^{86}$ However, although many articles have reported on the application of MBRs to the treatment of urban and industrial wastewaters, there are few papers reporting on the behavior of emerging contaminants during MBR treatment. ${ }^{87-89}$
Kim et al. ${ }^{12}$ studied the removal of pharmaceuticals in municipal sewage treatment in a MBR pilot plant and obtained a removal efficiency of $99 \%$ for acetaminophen and ibuprofen, but no decreases in the concentration of erythromycin, trimethoprim, naproxen, diclofenac and carbamazepine were observed.

Quintana et al..$^{90}$ studied the degradation of 5 different pharmaceuticals by activated sludge treatment, in the laboratory scale, as well as their occurrence and removal in municipal sewage treated by MBR. They reported that during the microbial degradation of the compounds, new metabolites could be detected and identified by LC-MS for ketoprofen, benzafibrate, naproxen and ibuprofen, while no transformation products were observed for diclofenac.

Kimura et al. ${ }^{21}$ compared the removal of 7 different pharmaceuticals on treating municipal wastewater using a MBR in parallel with conventional activated sludge. The removal efficiency was higher for the MBR than the conventional activated sludge treatment in the case of the compounds ketoprofen and naproxen. However, there was no significant difference with respect to the removal of compounds containing chlorine in their molecules.

Göbel et al. ${ }^{84}$ studied the removal of antibiotics in MBRs and reported that the removal of roxithromycin ranged from 39\%, for a SRT of 16 days, to $60 \%$, for longer SRTs (33 and 60 days). They also reported a removal efficiency of around $80 \%$ for sulfamethoxazole, regardless of the SRT, and removal efficiency for trimethoprim of $30 \%$ for SRTs of 16 days and 33 days, while $87 \%$ of removal was obtained for SRTs of 60-80 days.

Furthermore, AOPs represent an excellent tool for the elimination of organic pollutants by partly degradation or mineralization in water which are refractory to conventional (biological) treatments. Their interesting features are generally ascribed to the intervention of unselective and reactive hydroxyl radicals $\left({ }^{\circ} \mathrm{OH}\right)$, whose presence is a common characteristic of this type of processes. The generation of ${ }^{\bullet} \mathrm{OH}$ radicals is achieved through the utilization of oxidants such as ozone and $\mathrm{H}_{2} \mathrm{O}_{2}$, often in combination, and with or without UV radiation..$^{57,91}$ The adoption of AOPs in the tertiary treatment section of existing STPs can significantly contribute to the removal of the target compounds. The use of AOPs has been reported in the literature in the treatment of pulp and paper wastewater, ${ }^{92}$ tannery wastewater ${ }^{93}$ and wastewater containing pharmaceuticals. , $22,94-97^{-9}$ 
Nakajima et al. ${ }^{98}$ studied the photodynamic action of ketoprofen, determining the generation of free radicals and active oxygen species by photo-irradiation, as well as the identification of 3 different degradation products.

Limited data are available on the degradation of naproxen and the products formed. According to Isidori et al. ${ }^{99}$ phototransformation appears to be mainly responsible for the removal of this compound from the environment, where naproxen in water can be partly transformed by irradiation into different photoproducts. The same authors reported that several naproxen photodegradation products were more toxic than the parent compound, as previously confirmed by toxicity assays using Daphnia magna and Vibrio fischeri. ${ }^{100}$

Andreozzi et al. ${ }^{101}$ have applied high quantities of oxidation reagents in excess for the complete mineralization of acetaminophen via ozonation and $\mathrm{H}_{2} \mathrm{O}_{2} / \mathrm{UV}$ in aqueous solutions. At $\mathrm{pH}$ values of 2.0 and $7.0,800 \mathrm{mg} / \mathrm{L}$ of acetaminophen was completely mineralized within $20 \mathrm{~min}$ of reaction and up to $30 \%$ of the TOC was removed after $120 \mathrm{~min}$ using $72 \mathrm{~g} / \mathrm{h}$ of $\mathrm{O}_{3}$, while slightly lower oxidation rates were reached using $170 \mathrm{mg} / \mathrm{L} \mathrm{H}_{2} \mathrm{O}_{2} / \mathrm{UV}$ at $\mathrm{pH} 5.5$ (up to $90 \%$ of 1.51 $\mathrm{mg} / \mathrm{L}$ acetaminophen was degraded, and $40 \%$ of TOC was removed).

Shemer et al. ${ }^{102}$ studied the degradation of the drug metronidazole by UV irradiation, Fenton and photo-Fenton processes and reported that it followed pseudo-first-order reaction kinetics. It was also reported that the removal efficiency of the compound could be increased by $20 \%$ for the photo-Fenton process compared to the Fenton process.

Gonzalez et al. ${ }^{103}$ reported the removal of sulfamethoxazole (200 $\mathrm{mg} / \mathrm{L}$ ) using the photo-Fenton process while a complete removal was achieved under $\mathrm{a}_{2} \mathrm{O}_{2}$ dose of $\geq 300 \mathrm{mg} / \mathrm{L}\left(\left[\mathrm{Fe}^{2+}\right]=10 \mathrm{mg} / \mathrm{L}\right)$. Under these conditions biodegradability expressed as $\mathrm{BOD}_{5} / \mathrm{COD}$ ratio was increased from zero for the untreated sulfamethoxazole solution to values higher than 0.3 for the treated solution.

According to Ikehata et al. ${ }^{28}$ sulfamethoxazole is readily degradable by ozonation, like many other aromatic sulfonamide antibiotics. Ternes et al. ${ }^{104}$ demonstrated that $5 \mathrm{mg} / \mathrm{L}$ of applied ozone completely removed $0.62 \mu \mathrm{g} / \mathrm{L}$ of sulfamethoxazole present in a biologically treated municipal wastewater to a concentration below the detection limit. Similar results have been reported elsewhere. ${ }^{105}$ Several ozonation products were determined and identified by high resolution MS. ${ }^{106}$

Adams et al. ${ }^{107}$ demonstrated rapid conversion of trimethoprim by ozonation in a pre-filtered river water sample spiked to reach an initial concentration of $50 \mu \mathrm{g} / \mathrm{L}$. More than $95 \%$ of the antibiotic was converted by ozonation within $1.5 \mathrm{~min}$ applying an ozone dose of $0.3 \mathrm{mg} / \mathrm{L}$ at $\mathrm{pH}$ 7.5. Ternes et al. ${ }^{104}$ reported a similar reactivity of trimethoprim originally present in biologically treated wastewater during ozonation.

In addition, the use of activated carbon adsorption offers a further possible option to remove organic pollutants such as pharmaceuticals from wastewater. In fact, activated carbon in powdered or granulated form is able to remove unpolar and polar pollutants, e.g., drugs and even diagnostics like x-ray-contrast media from aqueous solutions because of the large adsorptive surface of the carbon which interacts with the comparable structural elements in the drug molecules. ${ }^{108}$ There are a considerable number of studies in the literature on the use of activated carbons in the treatment of liquid effluents containing metals, ${ }^{103}$ dyes $^{104}$ and phenolic compounds. ${ }^{105}$ However, studies concerning the removal of pharmaceuticals by activated carbon are quite rare.

Önal et al. ${ }^{26}$ studied the adsorption of naproxen sodium onto activated carbon (BET area of $1060 \mathrm{~m}^{2} / \mathrm{g}$ ) prepared from apricot waste. Adsorption of naproxen sodium onto activated carbon increased slightly with an increase in temperature, indicating that the process is endothermic. It was also reported that the Langmuir equation was found to represent the adsorption isotherm of naproxen sodium onto the activated carbon in an optimized way under a Langmuir equilibrium constant of $54.68 \mathrm{~L} / \mathrm{g}$ at $25^{\circ} \mathrm{C}$.
The adsorption of trimethoprim onto montmorillonite KSF and montmorillonite $\mathrm{K} 10$ was recently reported by Bekçi et al. ${ }^{25}$ and Bekçi et al. ${ }^{112}$ respectively. It was found that the adsorption isotherms for these systems were best fitted by the Langmuir isotherm. The Langmuir equilibrium constants reported by Bekçi et al. ${ }^{25}$ were in the range of $0.70-2.60 \mathrm{~L} / \mathrm{g}$, while Bekçi et al. ${ }^{112}$ reported constants in the range $4.72-6.54 \mathrm{~L} / \mathrm{g}$.

Bajpai et $a l .{ }^{24}$ studied the adsorption of sulfonamide antibiotics onto alumina (BET area of $18 \mathrm{~m}^{2} / \mathrm{g}$ ) and reported that the sulfonamide compounds discussed in their study were physically adsorbed onto alumina and obeyed the Langmuir adsorption isotherm equation. It was also found that the adsorption of sulfonamide compounds onto alumina decreases with increasing temperature. The Langmuir equilibrium constant reported for an initial sulfamethoxazole concentration in the range $507-7598 \mathrm{mg} / \mathrm{L}$ at $25^{\circ} \mathrm{C}$ and $\mathrm{pH} 7.2$ was $555 \mathrm{~L} / \mathrm{g}$.

Gereli et al. ${ }^{113}$ studied the adsorption of the cationic drug promethazine hydrochloride from aqueous solution onto K10 montmorillonite at $17.5,25$ and $30{ }^{\circ} \mathrm{C}$ and reported Langmuir equilibrium constants of $21.35,84.96$ and $115.14 \mathrm{~L} / \mathrm{g}$, respectively.

From the operational point of view, advanced treatment technologies can be applied to the degradation of pharmaceutical compounds present in STPs. MBR technology could replace the conventional biologic treatment such as activated sludge. AOPs, activated carbon adsorption or membrane treatment applying nano filtration (NF) can be applied as post-treatment. Partial treatment may be sufficient if the effluent will be discharged into surface water, although it is still needed to eliminate aquatic toxicity and improve biodegradability. However, if the effluent will supplement drinking water sources, complete removal or destruction of pharmaceuticals may be desired. In effluents of STPs, the removal of such compounds would avoid the contamination of surface water and, consequently, the effects on aquatic organisms would be minimized.

\section{CONCLUSIONS}

Pharmaceutical compounds and their biological degradation products (metabolites) are found as trace and ultra trace pollutants in STP effluents and in the aquatic environment at low concentrations (ng/L or $\mu \mathrm{g} / \mathrm{L}$ ), according to several research studies carried out all over the world.

The analysis of pharmaceutical residues in environmental matrices, such as STP effluents, river water, sediments and soil, still requires the development of more sensitive analytical methods suitable for the detection of trace and ultra trace pollutants at very low concentrations.

With regard to the toxic effects in the environment, most of the studies published in the literature indicate that pharmaceutical residues in aquatic compartments of the environment as pollutants of concern may represent a risk of acute toxicity to the environment. However, there is a general lack of data referring to the chronic toxicity of drugs, mainly in fish. For many drugs, further studies need to be carried out on their long-term ecotoxicological effects, primarily with regard to endocrine disruption, immune system disorders and gene mutation. Current data available on the toxicity of pharmaceuticals (acute effects) are insufficient for the elucidation of drug toxicity, both towards aquatic organisms and humans. Studies on possible chronic effects of individual drugs and/or their mixtures may provide important data on the risks which these compounds represented in different ecosystems.

Important aspects to be addressed are the pharmaceutical waste loads currently present in surface waters and their fate in the environment. Also, in order to achieve the discharge of these compounds into surface waters, current STP treatment processes need to be improved by the application of advanced treatment technologies such as mem- 
brane bioreactors (MBRs), advanced oxidation processes (AOPs) and activated carbon adsorption. In conclusion, further research in this field is required to assess the environmental risks associated with the presence of pharmaceutical compounds and their metabolites in the environment.

\section{ACKNOWLEDGEMENTS}

The authors would like to thank the Coordenação de Aperfeiçoamento de Pessoal de Nível Superior (CAPES) and the Deutscher Akademischer Austausch Dienst (DAAD, German Academic Exchange Service) for financial support. Analytical support from the staff of the Environmental Analytical Laboratory of the Institute of Environmental Engineering of RWTH Aachen University is also greatly appreciated.

\section{REFERENCES}

1. Ternes, T. A.; Water Res. 1998, 32, 3245.

2. Stumpf, M.; Ternes, T. A.; Wilken, R. D.; Rodrigues, S. V.; Baumann, W.; Sci. Total Environ. 1999, 225, 135.

3. Andreozzi, R.; Marotta, R.; Paxéus, N.; Chemosphere 2003, 50, 1319.

4. Gebhardt, W.; Schröder, H. Fr.; J. Chromatogr., A 2007, 1160, 34.

5. Castiglioni, S.; Fanelli, R.; Calamari, D.; Bagnati, R.; Zuccato, E.; Regul. Toxicol. Pharmacol. 2004, 39, 25.

6. Brown, K. D.; Kulis, J.; Thomson, B.; Chapman, T. H.; Mawhinney, D. B.; Sci. Total Environ. 2006, 366, 772.

7. Yang, S.; Carlson, K.; Water Res. 2003, 37, 4645.

8. Roberts, P. H.; Thomas, K. V.; Sci. Total Environ. 2006, 356, 143.

9. Hirsch, R.; Ternes, T.; Haberer, K.; Kratz, K. L.; Sci. Total Environ. 1999, 225,109

10. Kümmerer, K.; Chemosphere 2001, 45, 957.

11. Petrović, M.; Gonzalez, S.; Barceló, D.; Trends Anal. Chem. 2003, 22, 685.

12. Kim, S. D.; Cho, J.; Kim, I. S.; Vanderford, B. J.; Snyder, S. A.; Water Res. $\mathbf{2 0 0 7 , 4 1 , 1 0 1 3 . ~}$

13. Stackelberg, P. E.; Gibs, J.; Furlong, E. T.; Meyer, M. T.; Zaugg, S. D.; Lippincott, R. L.; Sci. Total Environ. 2007, 377, 255.

14. Halling-Sørensen, B.; Nielsen, S. N.; Lanzky, P. F.; Ingerslev, F.; Lützhøft, H. C. H.; Jørgensen, S. E.; Chemosphere 1998, 36, 357.

15. Sumpter, J. P.; Toxicol. Lett. 1998, 102, 337.

16. Kümmerer, K.; J. Antimicrob. Chemother. 2004, 54, 311.

17. Bila, D. M.; Dezotti, M.; Quim. Nova 2003, 26, 523.

18. Bila, D. M.; Dezotti, M.; Quim. Nova 2007, 30, 651.

19. Ghiselli, G.; Jardim, W. F.; Quim. Nova 2007, 30, 695.

20. Stackelberg, P. E.; Furlong, E. T.; Meyer, M. T.; Zaugg, S. D.; Henderson, A. K.; Reissman, D. B.; Sci. Total Environ 2004, 329, 99.

21. Kimura, K.; Hara, H.; Watanabe, Y.; Desalination 2005, 178, 135.

22. Andreozzi, R.; Canterino, M.; Marotta, R.; Paxéus, N.; J. Hazard. Mater. 2005, 122, 243.

23. Zhang, X.; Wu, F.; Wu, X.; Chen, P.; Deng, N.; J. Hazard. Mater. 2008, $157,300$.

24. Bajpai, A. K.; Rajpoot, M.; Mishra, D. D.; Colloid Surf. A 2000, 168, 193.

25. Bekçi, Z.; Seki, Y.; Yurdakoç, M. K.; J. Hazard. Mater. 2006, B133, 233.

26. Önal, Y.; Akmil-BaŞar, Ç.; Sarıcı-Özdemir, Ç.; J. Hazard. Mater. 2007, 148, 727.

27. Lipinski, C. A.; Lombardo, F.; Dominy, B. W.; Feeney, P. J.; Adv. Drug Deliv. Rev. 1997, 23, 3 .

28. Ikehata, K.; Naghashkar, N. J.; El-Din, M. G.; Ozone: Sci. Technol. 2006, $28,353$.

29. Fent, K.; Weston, A. A.; Caminada, D.; Aquatic Toxicol. 2006, 76, 122.

30. Daughton, C. G.; Ternes, T. A.; Environ. Health Perspect. 1999, 107, 907.

31. Takagi, T.; Ramachandran, C.; Bermejo, M.; Yamashita, S.; Yu, L.; Amidon, G.; Mol. Pharm. 2006, 3, 631.
32. Kümmerer, K.; J. Antimicrob. Chemother. 2003, 52, 5.

33. Gartiser, S.; Urich, E.; Alexy, R.; Kümmerer, K.; Chemosphere 2007, 67, 604.

34. Gulkowska, A.; He, Y.; So, M. K.; Yeung, L. W. Y.; Leung, H. W.; Giesy, J. P.; Lam, P. K. S.; Martin, M.; Richardson, B. J.; Mar. Pollut. Bull. 2007, 54, 1287.

35. Khan, S. J.; Ongerth, J. E.; Chemosphere 2004, 54, 355.

36. Jones, O. A. H.; Voulvoulis, N.; Lester, J. N.; Water Res. 2002, 36, 5013.

37. Heberer, T.; Toxicol. Lett. 2002, 131, 5 .

38. Chien, Y. H.; Lai, H. T.; Liu, S. M.; Sci. Total Environ. 1999, 239, 81.

39. Garrison, A. W.; Pope, J. D.; Allen, F. R. In Identification and Analysis of Organic Pollutants in Water; Keith, C. H., ed.; Ann Arbor Science: Michigan,1976, p. 517-566.

40. Richardson, M. L.; Bowron, J. M.; J. Pharm. Pharmacol. 1985, 37, 1

41. Rogers, I. H.; Birtwell, I. K.; Kruznyski, G. M.; Water Pollut. Res. J. Can. 1986, $21,187$.

42. Cahill, J. D.; Furlong, E. T.; Burkhardt, M. R.; Kolpin, D.; Anderson, L. G.; J. Chromatogr., A 2004, 1041, 171 .

43. Castiglioni, S.; Bagnati, R.; Calamari, D.; Fanelli, R.; Zuccato, E.; J. Chromatogr., A 2005, 1092, 206.

44. González, S.; Petrovic, M.; Barceló, D.; Trends Anal. Chem. 2007, $26,116$.

45. Miao, X. S.; Koenig, B. G.; Metcalfe, C. D.; J. Chromatogr., A 2002, 952, 139.

46. Rodríguez, I.; Quintana, J. B.; Carpinteiro, J.; Carro, A. M.; Lorenzo, R. A.; Cela, R.; J. Chromatogr., A 2003, 985, 265.

47. Schröder, H. Fr.; J. Chromatogr., A 2003, 1020, 131.

48. Favier, M.; Sena, R. F.; José, H. J.; Bieling, U.; Schröder, H. Fr.; Proceedings of International Conference on Sustainable Sanitation, Fortaleza, Ceará, Brazil, 2007.

49. Ternes, T. A.; Stumpf, M.; Mueller, J.; Haberer, K.; Wilken, R. D.; Servos, M.; Sci. Total Environ. 1999, 225, 81.

50. Miao, X. S.; Bishay, F.; Chen, M.; Metcalfe, C. D.; Environ. Sci. Technol. 2004, 38, 3533.

51. Gulkowska, A.; Leung, H. W.; So, M. K.; Taniyasu, S.; Yamashita, N.; Yeung, L. W. Y.; Richardson, B. J.; Lei, A. P.; Giesy, J. P.; Lam, P. K. S.; Water Res. 2008, 42, 395.

52. Xu, W.; Zhang, G.; Li, X.; Zou, S.; Li, P.; Hu, Z.; Li, J.; Water Res. 2007, $41,4526$.

53. Carballa, M.; Omil, F.; Lema, J. M.; Water Res. 2005, 39, 4790.

54. Santos, J. L.; Apacicio, I.; Alonso, E.; Environ. Int. 2007, 33, 596.

55. Tauxe-Wuersch, A.; De Alencastro, L. F.; Grandjean, D.; Tarradellas, J.; Water Res. 2005, 39, 1761.

56. Karthikeyan, K. G.; Meyer, M. T.; Sci. Total Environ. 2006, 361, 196.

57. Melo, S. A. S.; Trovó, A. G.; Bautitz, I. R.; Nogueira, R. F. P.; Quim. Nova 2009, 32, 188.

58. Barnes, K. K.; Kolpin, D. W.; Furlong, E. T.; Zaugg, S. D.; Meyer, M. T.; Barber, L. B.; Sci. Total Environ. 2008, 402, 192.

59. Focazio, M. J.; Kolpin, D. W.; Barnes, K. K.; Furlong, E. T.; Meyer, M. T.; Zaugg, S. D.; Barber, L. B.; Thurman, M. E.; Sci. Total Environ. 2008, 402, 201.

60. Moldovan, Z.; Chemosphere 2006, 64, 1808.

61. Sacher, F.; Lange, F. T.; Brauch, H. J.; Blankenhorn, E. I.; J. Chromatogr., A 2001, 938, 199.

62. Jones, O. A. H.; Lester, J. N.; Voulvoulis, N.; Trends Biotechnol. 2005, 23,4 .

63. Kosjek, T.; Heath, E.; Krbavcic, A.; Environ. Int. 2005, 31, 679.

64. Carballa, M.; Omil, F.; Lema, J. M.; Llompart, M.; García-Jares, C.; Rodríguez, I.; Gómez, M.; Ternes, T.; Water Res. 2004, 38, 2918.

65. Clara, M.; Strenn, B.; Gans, O.; Martinez, E.; Kreuzinger, N.; Kroiss, H.; Water Res. 2005, 39, 4797.

66. Sanderson, H.; Brain, R. A.; Johnson, D. J.; Wilson, C. J.; Solomon, K. R.; Toxicology 2004, 203, 27.

67. Jørgensen, S. E.; Halling-Sørensen, B.; Chemosphere 2000, 40, 691. 
68. Mills, L. J.; Chichester, C.; Sci. Total Environ. 2005, 343, 1.

69. Kümmerer, K.; Steger-Hartmann, T.; Meyer, M.; Water Res. 1997, 31, 2705.

70. Buser, H. R.; Poiger, T.; Müller, M. D.; Environ. Sci. Technol. 1998, 32, 3449.

71. Ternes, T.; Jos, A.; Siegrist, H.; Environ. Sci. Technol. 2004, 393.

72. Urase, T.; Kikuta, T.; Water Res. 2005, 39, 1289.

73. Golet, E. M.; Alder, A. C.; Giger, W.; Environ. Sci. Technol. 2002, 36, 3645 .

74. Temes, T. A.; Andersen, H.; Gilberg, D.; Bonerz, M.; Anal. Chem. 2002, $74,3498$.

75. Kreuzinger, N.; Clara, M.; Strenn, B.; Kroiss, H.; Water Sci. Technol. 2004, 50,149

76. Metcalfe, C. D.; Koenig, B. G.; Bennie, D. T.; Servos, M.; Ternes, T. A.; Hirsch, R.; Environ. Toxicol. Chem. 2003, 22, 2872.

77. Panter, G. H.; Thompson, R. S.; Beresford, N.; Sumpter, J. P.; Chemosphere 1999, 38, 3579.

78. D’Ascenzo, G.; Di Corcia, A.; Gentili, A.; Mancini, R.; Mastropasqua, R.; Nazzari, M.; Samperi, R.; Sci. Total Environ. 2003, 302, 199.

79. Jones, O. A. H.; Voulvoulis, N.; Lester, J. N.; Environ. Pollut. 2007, 145, 738.

80. Nakada, N.; Tanishima, T.; Shinohara, H.; Kiri, K.; Takada, H.; Water Res. 2006, 40, 3297.

81. Lindqvist, N.; Tuhkanen, T.; Kronberg, L.; Water Res. 2005, 39, 2219.

82. Clara, M.; Strenn, B.; Kreuzinger, N.; Water Res. 2004, 38, 947.

83. van Der Hoeven, N.; Acta Biotheor. 2004, 52, 201.

84. Göbel, A.; McArdell, C. S.; Joss, A.; Siegrist, H.; Giger, W.; Sci. Total Environ. 2007, 372, 361.

85. Larsen, T. A.; Lienert, J.; Joss A.; Siegrist, H.; J. Biotechnol. 2004, 113, 295.

86. Lyko, S.; Wintgens, T.; Al-Halbouni, D.; Baumgarten, S.; Tacke, D.; Drensla, K.; Janot, A.; Dott, W.; Pinnekamp, J.; Melin, T.; J. Membr. Sci. 2008, 317,78

87. Bernhard, M.; Müller, J.; Knepper, T. P.; Water Res. 2006, 40, 3419.

88. Schröder, H. Fr.; Water Practice \& Technology, IWA Publishing 2006; DOI10.2166/wpt.2006.0060

89. Wintgens, T.; Gallenkemper, M.; Melin, T.; Desalination 2002, 146, 387.

90. Quintana, J. B.; Weiss, S.; Reemtsma, T.; Water Res. 2005, 39, 2654.
91. Andreozzi, R.; Marotta, R.; Water Res. 2004, 38, 1225.

92. Tambosi, J. L.; Domenico, M.; Schirmer, W.; José, H. J.; Moreira, R. F. P. M.; J. Chem. Technol. Biotechnol. 2006, 81, 1426.

93. Schrank, S. G.; José, H. J.; Moreira, R. F. P. M.; Schröder, H. Fr.; Chemosphere 2005, 60, 644 .

94. Bila, D.; Montalvão, A. F.; Azevedo, D. A.; Dezotti, M.; Chemosphere 2007, $69,736$.

95. Coelho, A. D.; Sans, C.; Agüera, A.; Gómez, M. J.; Esplugas, S.; Dezotti, M.; Sci. Total Environ. 2009, 407, 3572.

96. Schröder, H. Fr.; Meesters, R. J. W.; J. Chromatogr., A 2005, 1082, 110

97. Trovó, A. G.; Melo, S. A. S.; Nogueira, R. F. P.; J. Photochem. Photobiol. A 2008, 198, 215.

98. Nakajima, A.; Tahara, M.; Yoshimura, Y.; Nakazawa, H.; J. Photochem. Photobiol., A 2005, 174, 89 .

99. Isidori, M.; Lavorgna, M.; Nardelli, A.; Parrella, A.; Previtera, L.; Rubino, M.; Sci. Total Environ. 2005, 348, 93.

100. Brigante, M.; Della Greca, M.; Isidori, M.; Nardelli, A.; Previtera, L.; Rubino, M.; Environ. Chem. Lett. 2004, 1, 237.

101. Andreozzi, R.; Caprio, V.; Marotta, R.; Vogna, D.; Water Res. 2003, 37, 993. 102. Shemer, H.; Kunukcu, Y. K.; Linden, K. G.; Chemosphere 2006, 63, 269.

103. González, O.; Sans, C.; Esplugas, S.; J. Hazard. Mater. 2007, 146, 459.

104. Ternes, T. A.; Stuber, J.; Hermann, N.; McDowell, D.; Ried, A.; Kampmann, M.; Teiser, B.; Water Res. 2003, 37, 1976.

105. Huber, M. M.; Canonica, S.; Park, G. Y.; Gunten, U. V.; Environ. Sci. Technol. 2003, 37, 1016

106. Abellán, M. N.; Gebhardt, W.; Schröder, H. Fr.; Proceedings of $5^{\text {th }} I W A$ Leading-Edge Conference on Water and Wastewater Technologies, Zürich, Switzerland, 2008.

107. Adams, C.; Wang, Y.; Loftin, K.; Meyer, M.; J. Environ. Eng.-ASCE 2002, $128,253$.

108. Mestre, A. S.; Pires, J.; Nogueira, J. M. F.; Carvalho, A. P.; Carbon 2007, 45, 1979.

109. Kobya, M.; Bioresour. Technol. 2004, 91, 317.

110. Purkait, M. K.; DasGupta, S.; De, S.; J. Environ. Manage. 2005, 76, 135.

111. Moreno-Castilla C.; Carbon 2004, 42, 83.

112. Bekçi, Z.; Seki, Y.; Yurdakoç, M. K.; J. Mol. Struct. 2007, 827, 67.

113. Gereli, G.; Seki, Y.; 'Kuşoğlu, I. M.; Yurdakoç, M. K.; J. Colloid Interface Sci. 2006, 299, 155. 